\title{
Factors Affecting Continuance Intention of FinTech Payment among Millennials in Jakarta
}

\author{
Norma Diana and Farah Margaretha Leon
}

\begin{abstract}
The background of this research is related to a phenomenon of millennials who prefer to change their financial behavior into cashless transactions from cash-based transactions. Factors of benefits (economic benefits, seamless transactions, and convenience) and risks (financial risks, legal risks, security risks, and operational risks) experienced by millennials are examined to observe their effects on the continuance intention of financial technology (FinTech) payment. FinTech users are classified into two types, namely early adopters and late adopters. This study examines the variables of continuance intention of FinTech payment, economic benefits, seamless transactions, convenience, financial risks, legal risks, security risks, operational risks, perceived benefits, and perceived risks simultaneously and is the first to be conducted on millennials in Jakarta. The methodology used was the Structural Equation Modeling-Partial Least Square. The data were collected through questionnaires distributed to 313 respondents. The results of this research show that convenience is the most influential benefit factor towards the continuance intention of FinTech payment. Operational risks are the only factor that do not significantly affect the continuance intention of FinTech payment. The differences between the effects of benefits and risks are found in both of the user types. The implication of this research is to further understand influential factors in millennials' decisions to use FinTech payment services.
\end{abstract}

Index Terms-Continuance Intention of FinTech Payment, Millennials, Perceived Benefits and Risks, User Type.

\section{INTRODUCTION}

Research from [1] states that millennials are those who were born in 1980-2000. This type of generation, according to the research, is closely related to a demographic bonus that has occurred in Indonesia. The phenomenon of millennials is marked with a significant increase in the number of productive-age population, which could be a golden opportunity for the Indonesian economy.

One behavior of millennials that attracts attention is their cashless lifestyle. From the aspect of cashless financial product ownership, millennials infrequently carry a significant amount of cash. This habit is worth researching, in relation to their preferences to use FinTech products in Indonesia, specifically in large cities such as Jakarta.

In Indonesia, the growth of the FinTech industry has arguably been remarkable. Estimated to have emerged in 2006, the Indonesian FinTech industry achieved a total transaction value of USD 15.02 billion (IDR 202.77 trillion) in 2017, which grew by $24.6 \%$ from the previous year. Four factors that have catalyzed this massive development of FinTech in Indonesia include easiness, innovative development of technology, millennials, and flexibility [2]. According to [3], there are three benefit and four risk factors that significantly affect the utilizations of FinTech in Korea. Those factors are studied based on the two types of users that he classifies as early adopters and late adopters.

According to [4], 50\% of 265.4 million Indonesian people are active internet users. The internet has also changed the competitive dimension in the banking sector through their products including phone banking service, which has served as the first step towards the growth of financial inclusion, specifically electronic finance [5].

[6] states that the number of accounts in commercial banks in Indonesia per March 2019 was 282 million accounts. The massive penetration of the internet, the high increase in number of customers in commercial banks in Indonesia, and the high number of millennial population may serve as a strong foundation to operate technology-based financial inclusion activities addressed to millennials working in Jakarta. Therefore, the authors undertake this topic to be further studied academically. This empirical research gives a new understanding of the benefits and risk factors that affect the continuance intention of FinTech payment among millennials working in Jakarta, who are classified into two types of users, namely early adopters and late adopters.

\section{LITERATURE REVIEW}

\section{A. Financial Technology Payment}

According to [7], four main categories of FinTech products include transaction and payment, loan, investment and wealth management, and insurance. [8] also said that there are several models on the evolution of financial innovation such as peer-to-peer lending, crowd funding, e-money, and mobile payment. In Indonesia, FinTech products usually refer to mobile payment (m-payment) products.

Big banks, telecommunication companies, securities companies, and e-commerce already have their own versions of FinTech products, for example, BCA with Sakuku, Bank Tabungan Pensiunan Nasional (BTPN Bank) with Jenius, Telkomsel with LinkAja, Go-Jek with Go-Pay, Grab with OVO, Shopee with ShopeePay, and others. These financial products are growing rapidly and gaining very good responses from people. 


\section{B. The Millennial Generation}

According to [1], the millennial generation refers to the population born in 1980-2000. The characteristics of millennials, as explained by [9], are a generation known for optimism, attachment, and the will to take risks. They are the first consumer group who grow in an internet-based world and are frequently a type of early adopters. They feel more convenient with technology and gadgets than their parents [10]. [9] also add that millennials understand technology better and are more educated and more ethnically diverse than the previous generations.

\section{Perceived Benefits and Risks}

Perceived benefits are defined as perceptions that the use of FinTech would result positively [3]. Economic benefits are the most common extrinsic motivations for FinTech [11]. Seamless transactions refer to benefits of doing transactions with FinTech (for example: purchasing, remittance, loan, and investment). Convenience is one of FinTech's extrinsic motivations that refers to time and location flexibility [12], and one of the most important factors of the success of online and mobile services [13].

Perceived risks are the main obstacle for users while considering the use of FinTech. Financial risks refer to potential financial losses in FinTech financial transactions [3]. Legal risks refer to uncertain legal status and insufficient regulations on FinTech. Security risks are defined as potential losses from fraud or hacking during FinTech financial transactions, conceptualized as a violation of privacy, which has gained a huge attention from users. Operational risks are an obstacle for users that refers to potential losses due to system failures in the internal of the company, which is caused by an inadequate quality of FinTech systems and employees who run the company [14].

\section{The Classification of User Types}

This research classifies FinTech users into two categories: early adopters and late adopters [13]. Early adopters are more willing to try and use new technology and have a more positive attitude towards innovation, and also hope that the benefits of using FinTech are greater than the risks. Meanwhile, late adopters tend to be more inflexible to change. They are also skeptical of agents of change [15].

\section{HYPOTHESIS DEVELOPMENT}

Perceived benefits have been used for many times as a determinant factor for the continuance intention of a certain information system [16]. According to [17], users can perceive benefits in using mobile banking because of more flexibility and convenience. Research on mobile payment reveals that the perceived benefits significantly affect the utilizations of mobile payment [3]. The perceived risks are related to products or services which have gained a significance in research on consumers and innovation [18]. When users make a risky decision, they are willing to take a risk to gain profits or benefits [3]. A loan agreement by a financial institution needs trust, without exception, since there is always a risk for payment failure. Social trust reduces banks' risks because a company with the trust is expected to maintain the same behavior in the future [19]. The risks that are perceived significantly and negatively affect the usage of IT service [20]. Based on the opinions above, the hypotheses are formulated as follows:

$\mathrm{H}_{1}$ : There is a positive effect of perceived benefits (PB) on the continuance intention of FinTech payment $(\mathrm{CI})$.

$\mathrm{H}_{2}$ : There is a negative effect of perceived risks (PR) on the continuance intention of FinTech payment (CI).

Within the context of FinTech, the economic benefits consist of cost reduction and financial profits from FinTech transactions. Some FinTech applications, such as mobile remittance, give lower transaction fees compared to traditional financial services by facilitating standardized services directly without intermediation [21]. FinTech applications may also carry greater benefits to customers compared to traditional financial institutions [22]. According to [23], the phenomenon of growing artificial intelligence and robot-based systems, which never occurred before in multiple industries, gives an important effect on the economic, social, and labor fields. [3] describes in his research that there is a significant and positive effect of economic benefits on the perceived benefits.

Seamless transactions refer to the benefits related to transactions using FinTech [3]. [17] explain that the main things of the FinTech ecosystem are the users, good experience in a digital transaction, and the seamless services for them. The seamless transactions provide a stimulus that FinTech companies are capable of developing a new and innovative financial service to compete with traditional financial institutions and survive in the financial market [24].

Convenience refers to time and place flexibilities [12] as the most important factor in the success of online and mobile service [13]. Users can obtain convenience and efficiency that previously never existed through mobile gadgets, without having to visit financial institutions [25]. Convenience becomes the main factor in users' experience in using FinTech [26]. Convenience is the biggest factor perceived by users in terms of the benefits resulted from FinTech products [3]. Based on the opinions above, the hypotheses are formulated as follows:

$\mathrm{H}_{3}$ : There is a positive effect of economic benefits (EB) on the perceived benefits (PB).

$\mathrm{H}_{4}$ : There is a positive effect of seamless transactions (ST) on the perceived benefits (PB).

$\mathrm{H}_{5}$ : There is a positive effect of convenience $(\mathrm{CN})$ on the perceived benefits (PB).

Financial risks refer to potential financial losses in FinTech financial transactions [27]. A study in the literature of the information system finds that perceived financial risks are the most consistent predictor of the behavior of online and mobile services users [20]. The financial losses inflicted by FinTech services are caused by the malfunctioning of the financial transaction system, financial fraud, and additional transaction fees [24]. [3] finds that financial benefits positively and significantly affect the perceived benefits.

According to [3], legal risks refer to uncertain legal status and insufficient regulations for FinTech services. For example, the South Korean Government intervened aggressively in the management of Korean financial institutions and the financial market since the government regards financial service as public service. Therefore, South Korea has a strict financial regulation that can inhibit the 
entrance and growth of the FinTech businesses. Fraud is a broad legal concept and implicates the use of fraud to gain profits where it is a violation of the law [28]. According to [29], financial institutions can work practically, such as with financial contracts since they can be stated mathematically. However, legal contracts are always stated in a natural language. The dependence on a natural language has blurred the fundamental relation of natural mathematics, which has a massive consequence in the financial sector.

According to [30], data security is a factor which empirically affects both the users and the FinTech companies. Nowadays, digital security is the biggest problem [31]. According to [32], privacy is a matter that internet users mostly care about, hence creating a security system is very important. Consumers constantly worry about data and private information and how it would be used. The use of FinTech is related to the potential of fairly high losses [33]. The security risks affect the users in using FinTech services since there are fairly high risks perceived by the users [3].

According to [34], operational risks are related to a decrease in income resulting from operational incidents, such as losses inflicted by fraud which affect financial reports. Operational risks refer to the potential losses caused by inadequate internal processes, employees, and systems [14]. They can also include other risks in financial transactions, such as legal risk, fraud, physical risk, or environmental risk [35]. Based on some of the opinions above, the hypotheses are formulated as follows:

$\mathrm{H}_{6}$ : There is a positive effect of financial risks (FR) on the perceived risks (PR).
$\mathrm{H}_{7}$ : There is a positive effect of legal risks (LR) on the perceived risks (PR).

$\mathrm{H}_{8}$ : There is a positive effect of security risks (SR) on the perceived risks (PR).

$\mathrm{H}_{9}$ : There is a positive effect of operational risks (OR) on the perceived risks (PR).

Early adopters are referred to as individuals who are interested in adopting new technology or services and willing to take a risk [13]. This type of users is more willing to adopt and use new technology. They also have a more positive attitude towards innovation in information technology [15]. Moreover, this type of users hopes that the benefits of FinTech usage is greater than the risks [3]. Late adopters are referred to as individuals who are likely to be slow in adopting new technology and services [3]. They also tend to be skeptical of agents of change [15]. According to [34], the risks where strategic targets might not be fulfilled is caused by the less responses of the users or the tardiness on changing business environment and climate. Based on some of the opinions above, the hypotheses are formulated as follows:

$\mathrm{H}_{10}$ : The effects of perceived benefits (PB) on the continuance intention of FinTech payment (CI) in early adopters (EA) are greater than in late adopters (LA).

$\mathrm{H}_{11}$ : The effects of perceived risks (PR) on the continuance intention of FinTech payment (CI) in late adopters (LA) are greater than in early adopters (EA).

Based on the hypotheses above, the following is the summary of the model submitted in this research.

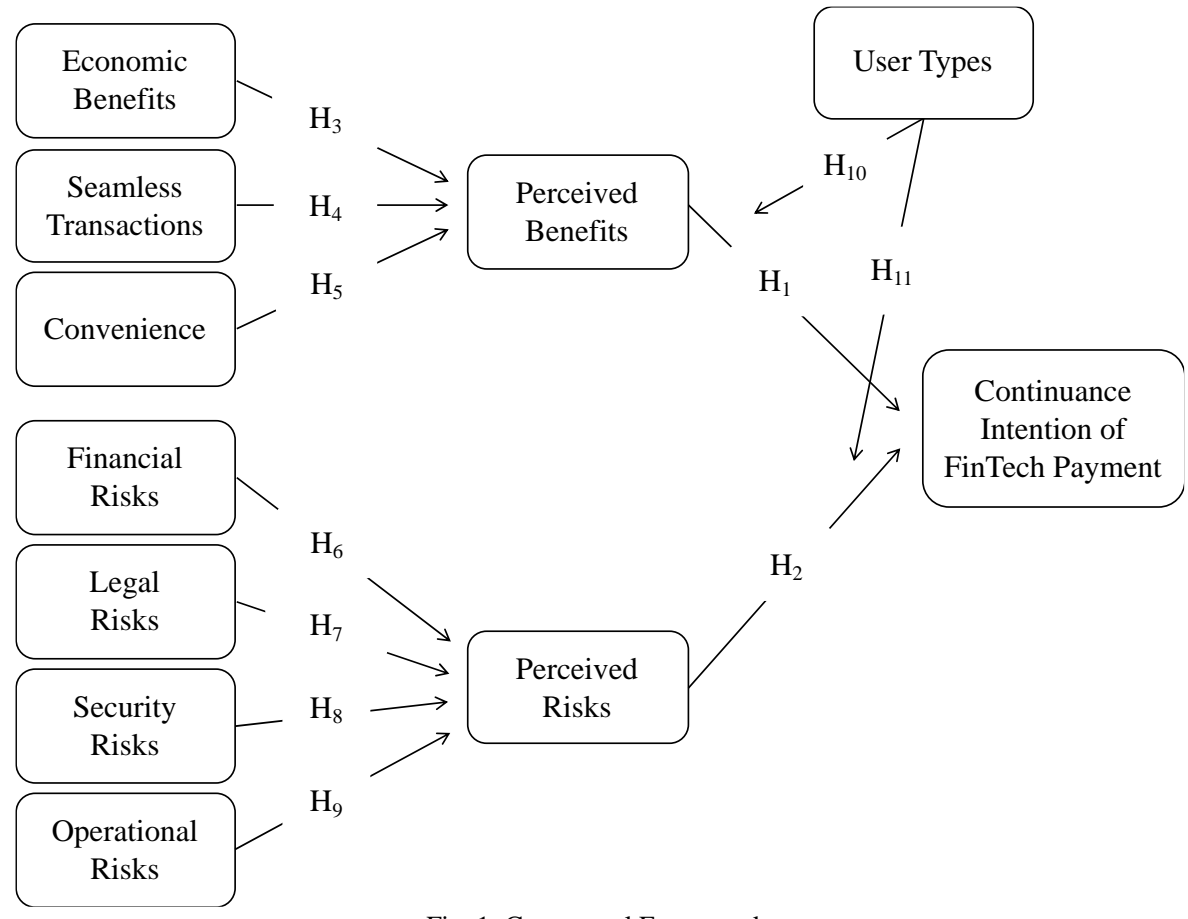

Fig. 1. Conceptual Framework.

\section{RESEARCH METHODOLOGY}

\section{A. Sample and Data Collection}

The selected samples for this research were the millennials working in the Greater Area of Jakarta and possessing more than one bank accounts. The bank accounts were not limited to certain banks, hence any bank accounts were included in the sample category. As mentioned in the previous chapter, the aforementioned millennials are individuals born in 19802000, hence in 2020 the respondents are 20-40 years old Furthermore, the respondents must also own at least one mobile or internet banking application, also at least one FinTech payment application. Therefore, the respondents owned at least two financial applications on their smartphones; banking and FinTech applications.

Of 477 questionnaires distributed for this research, only 
462 returned. However, only 149 of the 462 questionnaires could be analyzed since the respondents' profiles in the questionnaires did not meet the qualification, so that they were eliminated from the research. Therefore, a total of 313 questionnaires were proper to analyze and usable for this research. The questionnaire gathering period was taking place for six weeks by using 193 physical questionnaires, or $62 \%$ of the total respondents, and 120 online questionnaires via Google Form, or $38 \%$ of the total respondents. The following table is a summary of the entire respondents.

Before the final analysis, a Goodness of Fit (GOF) test was conducted to examine how well a certain model did in reproducing the covariance matrix among item indicators, such as the similarity in observed and predicted covariance matrix. The measurement of GOF can be seen from the value of $\mathrm{R}^{2}$ of the data processing. The result of the data processing shows the result of the GOF in this research with the value of R-Square in 0.410 as variable of the continuance intention of FinTech. This means that the model has a big GOF value and the bigger the value of GOF is, then more ideal it is in portraying the research samples.

TABLE I: DEMOGRAPHIC OF THE RESPONDENT

\begin{tabular}{|c|c|c|}
\hline Category & $\#$ & $\%$ \\
\hline \multicolumn{3}{|l|}{$\underline{\text { Sex }}$} \\
\hline$\overline{\text { Female }}$ & 188 & $60.1 \%$ \\
\hline Male & 125 & $39.9 \%$ \\
\hline Total & 313 & $100.0 \%$ \\
\hline \multicolumn{3}{|l|}{ Age } \\
\hline $20-26$ years old & 120 & $38.3 \%$ \\
\hline 27-33 years old & 130 & $41.5 \%$ \\
\hline $34-40$ years old & 63 & $20.1 \%$ \\
\hline Total & 313 & $100.0 \%$ \\
\hline \multicolumn{3}{|l|}{ Education } \\
\hline$<$ Diploma III & 38 & $12.4 \%$ \\
\hline Diploma III/IV & 20 & $6.4 \%$ \\
\hline Undergraduate & 195 & $62.3 \%$ \\
\hline Graduate & 57 & $18.2 \%$ \\
\hline Doctoral & 2 & $0.6 \%$ \\
\hline Total & 313 & $100.0 \%$ \\
\hline \multicolumn{3}{|l|}{ Occupation } \\
\hline Civil Servant/Military/Police & 11 & $3.5 \%$ \\
\hline Employee & 224 & $71.6 \%$ \\
\hline Teacher/Lecturer/Consultant & 11 & $3.5 \%$ \\
\hline Doctor/Nurse & 5 & $1.6 \%$ \\
\hline Others & 62 & $19.8 \%$ \\
\hline Total & 313 & $100.0 \%$ \\
\hline \multicolumn{3}{|l|}{ Income } \\
\hline$\leq$ IDR 3 million & 13 & $4.2 \%$ \\
\hline IDR 3.01 million - 6 million & 110 & $35.1 \%$ \\
\hline IDR 6.01 million - 9 million & 94 & $30.0 \%$ \\
\hline > IDR 9 million & 96 & $30.7 \%$ \\
\hline Total & 313 & $100.0 \%$ \\
\hline \multicolumn{3}{|l|}{ User Types } \\
\hline Early Adopters & 247 & $78.9 \%$ \\
\hline Late Adopters & 66 & $21.1 \%$ \\
\hline Total & 313 & $100.0 \%$ \\
\hline
\end{tabular}

\section{B. Measurement}

This research used primary data. The data were collected with the questionnaire technique, in which respondents were given written questions. Firstly, the questionnaire was provided to 50 respondents to further examine its validity and reliability. The assessment was conducted by using the 5 points in the Likert Scale, whereas the point (1) is for "strongly disagree" and the point (5) is for "strongly agree". The results of the validity test by using factor loadings technique (component matrix $>0.700$ ) in this research obtained that three-question items were invalid and later eliminated in the main survey. The reliability test in this research was examined by looking at the Cronbach's coefficient alpha (Cronbach's alpha $\geq 0.600$ ), resulting in the conclusion that all of the constructs were stated as reliable. Table II and III show the result of validity and reliability test

TABLE II: VALIDITY TEST

\begin{tabular}{ccc|ccc}
\hline \hline Item & Matrix & Result & Item & Matrix & Result \\
\hline CI1 & $0 . .732$ & Valid & LR2 & 0.833 & Valid \\
C12 & 0.667 & Invalid & LR3 & 0.246 & Invalid \\
C13 & 0.808 & Valid & LR4 & 0.826 & Valid \\
CI4 & 0.842 & Valid & SR1 & 0.856 & Valid \\
EB1 & 0.833 & Valid & SR2 & 0.926 & Valid \\
EB2 & 0.816 & Valid & SR3 & 0.915 & Valid \\
EB3 & 0.884 & Valid & OR1 & 0.801 & Valid \\
ST1 & 0.740 & Valid & OR2 & 0.945 & Invalid \\
ST2 & 0.716 & Valid & OR3 & 0.938 & Valid \\
ST3 & 0.866 & Valid & PR1 & 0.932 & Valid \\
CN1 & 0.842 & Valid & PR2 & 0.932 & Valid \\
CN2 & 0.893 & Valid & PR3 & 0.652 & Invalid \\
CN3 & 0.917 & Valid & PB1 & 0.858 & Valid \\
FR1 & 0.732 & Valid & PB2 & 0.737 & Valid \\
FR2 & 0.761 & Valid & PB3 & 0.817 & Valid \\
FR3 & 0.850 & Valid & PB4 & 0.737 & Valid \\
LR1 & 0.817 & Valid & & & \\
\hline \hline
\end{tabular}

TABLE III: RELIABILITY TEST

\begin{tabular}{llll}
\hline \hline \multicolumn{1}{c}{ Construct } & Items & Cronbach's a & Result \\
\hline Continuance Intention of & 3 & 0.707 & Reliable \\
FinTech Payment & 3 & 0.781 & Reliable \\
Economic Benefits & 3 & 0.668 & Reliable \\
Seamless Transactions & 3 & 0.858 & Reliable \\
Convenience & 3 & 0.673 & Reliable \\
Financial Risks & 3 & 0.766 & Reliable \\
Legal Risks & 3 & 0.881 & Reliable \\
Security Risks & 3 & 0.878 & Reliable \\
Operational Risks & 4 & 0.788 & Reliable \\
Perceived Benefits & 2 & 0.844 & Reliable \\
Perceived Risks & & & \\
\hline \hline
\end{tabular}




\section{ANALYSIS AND RESUlt}

To analyze the data, the Structural Equation Modelling (SEM) method was used as a statistical modeling technique deemed as suitable since it is cross-sectional, linear, and common. This method is also often used to build and test a statistical method which is causative, also to affirm correlations between the variables. SEM includes confirmatory factor analysis, path analysis, partial least squares path modeling, and latent growth model.

In this method, the Partial Least Square (PLS) method is used to examine the submitted model and its hypotheses. [3] recommends PLS for a predictive research model with an emphasis on the development of theory for its compatibility for explorative science.

\section{A. Measurement Model}

Before the final analysis, two steps of the evaluations were conducted: evaluation of the measurement model (outer model) and evaluation of the structural model (inner model). The outer model examined the convergent validity (loading factor $\geq 0.70$ ) and the average variance extracted (AVE > $0.50)$. From the two analyses, all indicators were stated as good and could be continued to the main survey. The analysis of the inner model was carried to find out whether the hypotheses could be accepted or rejected. This research would use the significant value (a) of 0.10 or $10 \%$. The relation between the variables can be considered as significant if the $p$-value is smaller than the set significant value $(p$-value $<0.10)$.

\section{B. Statistic Descriptive}

The following table explains the mean and standard deviation for the measured variables. The mean shows the average respondent ratings on the questions asked, while the standard deviation illustrates a magnitude of the deviation from the average of questions raised in the research questionnaires.

TABLE IV: STATISTIC DESCRIPTIVE

\begin{tabular}{lcccc}
\hline \multicolumn{1}{c}{ Variable } & Min. & Max. & Mean & Std. Dev. \\
\hline Continuance Intention & 1.00 & 5.00 & 4.1491 & 0.68754 \\
of FinTech Payment & & & & \\
Economic Benefits & 2.00 & 5.00 & 3.8903 & 0.80222 \\
Seamless Transactions & 1.33 & 5.00 & 3.8413 & 0.72503 \\
Convenience & 2.00 & 5.00 & 4.2705 & 0.66342 \\
Financial Risks & 1.00 & 5.00 & 2.6880 & 0.79186 \\
Legal Risks & 1.00 & 5.00 & 2.3275 & 0.74634 \\
Security Risks & 1.00 & 5.00 & 3.2737 & 0.96999 \\
Operational Risks & 1.00 & 5.00 & 3.0607 & 0.90240 \\
Perceived Benefits & 2.50 & 5.00 & 4.2181 & 0.60096 \\
Perceived Risks & 1.00 & 5.00 & 3.1661 & 0.93689 \\
\hline \hline
\end{tabular}

\section{Hypothesis Tests}

With a proper measurement model and a low multicollinearity level, all submitted hypotheses were examined using PLS. Path coefficient, $p$-value, and $\mathrm{R}^{2}$ were applied to examine the submitted model. The test of significance of all paths in the research model was conducted by using PLS resampling bootstrap procedure. In Figure 2, there are 8 paths in the model supported on level $\leq 0.10$, and 1 path on level $>0.10$. The result of the $\mathrm{R}^{2}$ test for the Continuance Intention of FinTech construct has the value of 0.410, which means the Perceived Benefits and Perceived Risks constructs can explain the Continuance Intention of FinTech payment construct at $41.0 \%$.

The following diagram shows a significant and positive effect of the perceived benefits on the Continuance Intention of FinTech payment $(B=0.622 ; p \leq 0.10)$, so that $H_{1}$ is accepted. Perceived risks significantly and negatively affect the Continuance Intention of FinTech payment $(ß=-0.080 ; p$ $\leq 0.10$ ), so that $\mathrm{H}_{2}$ is accepted. Economic benefits significantly and positively affects the perceived benefits ( ( $=0.312 ; p \leq 0.10)$, so that $\mathrm{H}_{3}$ is accepted. Seamless transactions significantly and positively affects the perceived benefits $(\beta=0.180 ; p \leq 0.10)$, so that $\mathrm{H}_{4}$ is accepted. Convenience significantly and positively affects the perceived benefits $(\beta=0.398 ; p \leq 0.10)$, so that $\mathrm{H}_{5}$ is accepted. Financial risks significantly and positively affect the perceived risks $(\beta=0.324 ; p \leq 0.10)$, so that $\mathrm{H}_{6}$ is accepted. Legal risks significantly and positively affect the perceived risks $\left(~(\beta=0.113 ; p \leq 0.10)\right.$, so that $\mathrm{H}_{7}$ is accepted. Security risks significantly and positively affect the perceived risks $(\beta=0.194 ; p \leq 0.10)$, so that $\mathrm{H}_{8}$ is accepted. Operational risks do not significantly affect the perceived risks $(\beta=0.076$; $p>0.10)$, so that $\mathrm{H}_{9}$ is rejected.

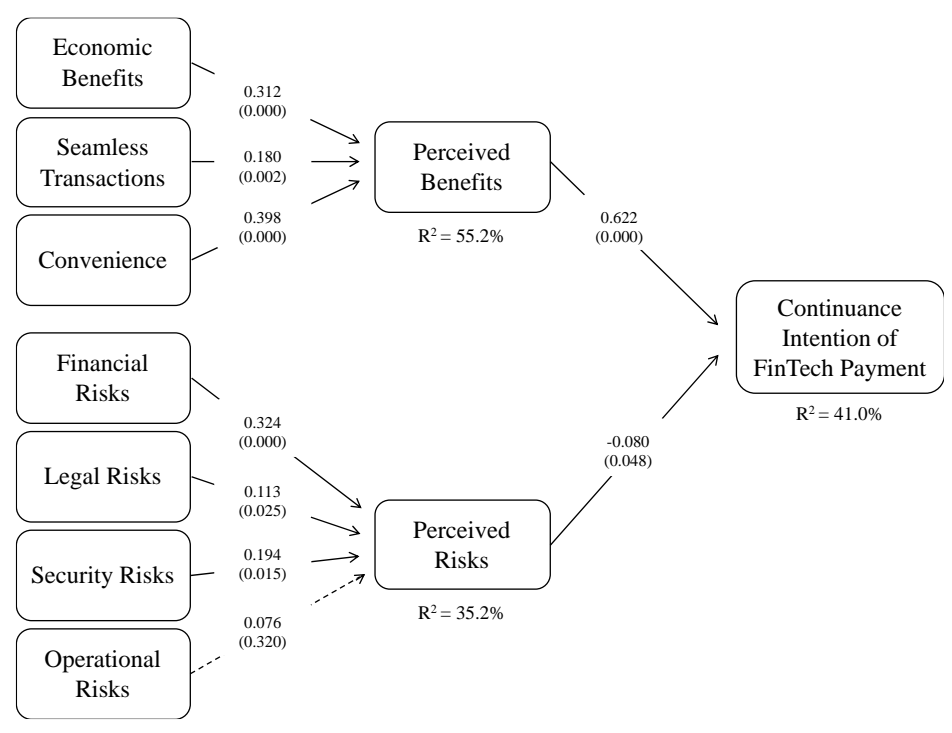

Fig. 2. The Result of Hypothesis Tests on All User Types

The two following diagrams show the results of the statistical examinations on $\mathrm{H}_{10}$ and $\mathrm{H}_{11}$. The coefficient of the perceived benefits on early adopters is 0.623 , with the $p$-value $\leq 0.10$, while the coefficient of the perceived benefits on late adopters is 0.621 , with the $p$-value $\leq 0.10$. Therefore, there is a greater significant and positive effect of the perceived benefits on the early adopters and the late adopters, so that $\mathrm{H}_{10}$ is accepted. The coefficient of the perceived risks on late adopters is -0.079 , with the $p$-value $\leq 0.10$, while the coefficient of the perceived risks on early adopters is -0.077 , with the $p$-value $\leq 0.10$. Therefore, there is a greater significant and negative effect of the perceived risks on the 
late adopters and the early adopters, so that $\mathrm{H}_{11}$ is accepted.

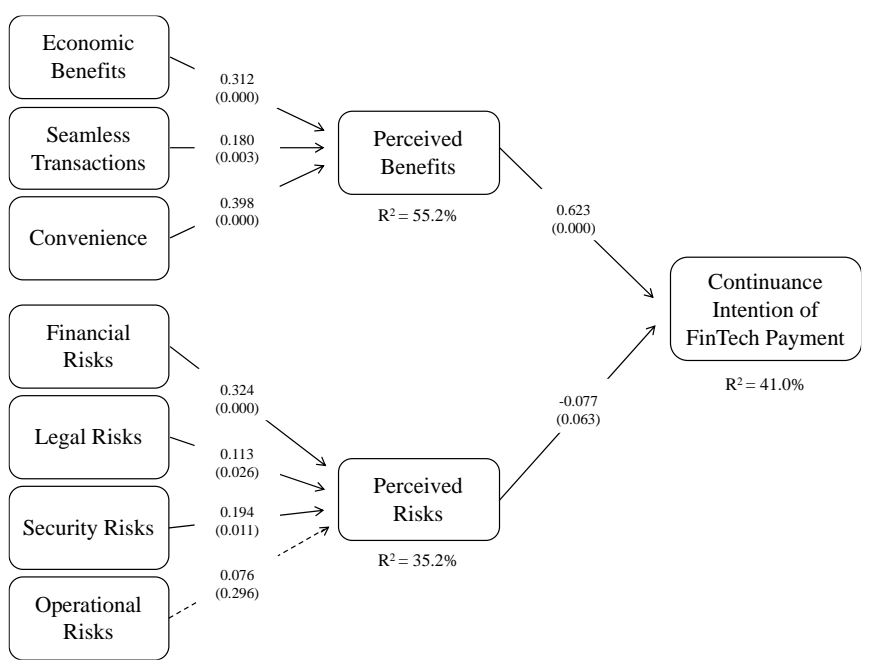

Fig. 3. The Result of Hypothesis Tests on Early Adopters

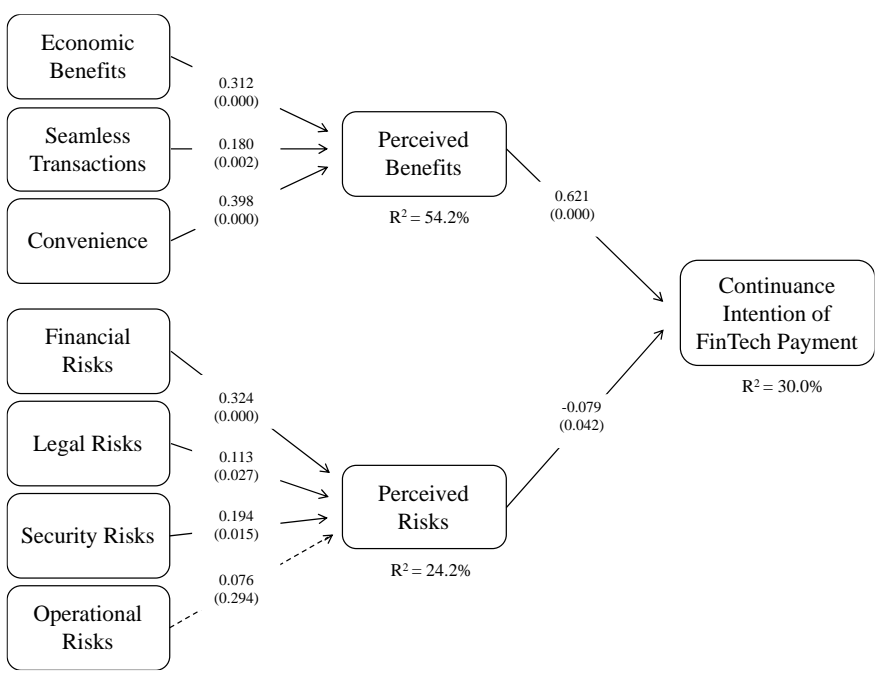

Fig. 4. The Result of Hypothesis Tests on Late Adopters

\section{DisCUSSION AND CONCLUSION}

\section{A. Discussion}

Hypothesis 1 shows that perceived benefits have a significant and positive effect on the continuance intention of FinTech payment. This value means the higher the perceived benefits of FinTech payment service are, the higher users' preferences to keep using FinTech payment, which affects the continuance intention of FinTech payment itself. This finding is supported by prior studies by [3], [36], and [37].

Hypothesis 2 shows that perceived risks have a significant and negative effect on the continuance of intention FinTech payment. It is then proven right that respondents fairly agree to consider risk factors of FinTech payments services. This was the result of descriptive statistical analysis which saw a construct of perceived risks by their average value (mean = 3.1661 ). This result corresponds to the conclusions of research by [3] and [20].

Hypothesis 3 shows that economic benefits have a significant and positive effect on the perceived benefits. It is proven significantly that there are economic benefits from the benefits perceived by FinTech payment users. This value means that the higher the economic benefits are, the higher the benefits perceived by users so that the continuance rate of FinTech payment also gets higher. This result is supported by earlier studies by [3] and [25].

Hypothesis 4 explains that seamless transactions have a significant and positive effect on the perceived benefits. Therefore, this corresponds with the submitted hypothesis that the seamless transactions have a significant and positive effect on the continuance intention of FinTech payment. This means that the seamless transactions affect users' decisionmaking process in using FinTech services in the future. This finding is supported by research by [3], [23], and [38].

Hypothesis 5 shows that convenience has a significant and positive effect on the perceived benefits. This value means that the higher the convenience experienced by users while doing digital finance transactions, the higher the perceived benefits, thus it affects the continuance intention of FinTech payment. Considering that the respondents in this research are millennials, it is clear that the ease of digital transactions is required to help their financial transaction activities, which will eventually end up in the continuance intention of FinTech payment services itself. This finding is backed up by research by [3], [16], and [27].

Hypothesis 6 shows that there is a significant and positive effect of financial risks on the perceived risks. This value means the higher the financial risk experienced by users while doing FinTech payment transactions, the higher the perceived risks, thus it affects the continuance intention of FinTech payment. The highest coefficient value is also found in the perceived risks category. The result is supported by [3], [20], and [37].

Hypothesis 7 shows that there is a significant and positive effect of legal risks on the perceived risks. This means that the higher the legal risks perceived by users while doing FinTech payment transactions, the higher the perceived risks, thus it affects the continuance intention of FinTech payment itself. This finding is in line with research by [3], [20], and [39].

Hypothesis 8 shows that there is a significant and positive effect of security risks on the perceived risks. Even though most of the respondents in this research are categorized as early adopters and are likely to take risks, security in conducting digital financial transactions still remains something that users pay attention to. This means that the hypothesis where security risks affect perceived risks is valid. This result is supported by [3], [30], and [40].

Hypothesis 9 shows that operational risks do not affect the perceived risks. Most respondents in this research are individuals working as private company employees, so that they are likely to believe that the internal system of companies must have been well-prepared, considering that the conducted transactions are financial transactions. Moreover, the system in financial technology companies must fulfill a tight requirement to operate, so this finding offers a new understanding that millennials who mostly work as private company employees do not consider operational risks, which may emerge from digital financial transactions. This contradicts the research by [3]. However, this finding is in line with research by [18], which explains that operational risks do not significantly affect the perceived risks.

Hypothesis 10 reveals that there is a greater significant and positive effect between the benefits perceived by early 
adopters and the benefits perceived by late adopters. This finding is supported by earlier research by [3] and [13].

Hypothesis 11 reveals that there is a larger significant and negative effect between the risks perceived by late adopters and the risks perceived by early adopters. This finding offers new insight that although the millennial generation is optimistic and fluent with internet characteristics, the late adopters keep considering risk factors compared to the early adopters. It is then proven right, as it has been explained in the previous chapter, that late adopters are likely to worry about new technology. This research is supported by [3] and [13].

\section{B. Conclusion}

Based on the analysis on the previous point, it can be concluded that:

1. There is a significant and positive effect of perceived benefits on the continuance intention of FinTech payment.

2. There is a significant and negative effect of perceived risks on the continuance intention of FinTech payment.

3. There is a significant and positive effect of economic benefits on the perceived benefits.

4. There is a significant and positive effect of seamless transactions on the perceived benefits.

5. There is a significant and positive effect of convenience on the perceived benefits.

6. There is a significant and positive effect of financial risks on the perceived risks.

7. There is a significant and positive effect of legal risks on the perceived risks.

8. There is a significant and positive effect of security risks and the perceived risks.

9. There is no effect of operational risks on the perceived risks.

10. There is a larger effect of the benefits perceived by early adopters than by late adopters.

11. There is a larger effect of the risks perceived by late adopters than by early adopters.

\section{IMPLICATION AND FUTURE WORK}

\section{A. Implication on the Managerial}

From the conclusions above, this research should be of use for parties who work in the FinTech payment industry. Millennials as the most numerous population greatly decide the continuance of technology and digital industry in the next few decades, therefore, this generation's behavior and intensity in using FinTech payment services must be observed well. Considering that convenience is the biggest factor that users pay attention to as a perceived benefit, service quality improvement needs to be of serious concern for further study by the managements of FinTech payment companies. An easy and concise payment journey and an aesthetic design interface are great ideas to make users feel more comfortable in using FinTech payment services. Spry customer service is also needed in order to give a secure and convenient feeling to customers if problems occur during financial transactions.

From the side of perceived risks, financial risks are the biggest factor considered by users in their decision in using FinTech payment services. This needs to be a bigger concern for the management to create a better and safer system, so that no financial loss caused by system disruption happens during transactions. Financial risks are also related to operational and security risks since the FinTech system works digitally and depends on the power of the system, server, database, and information technology (IT) to enable the transactions. Given the great effect of financial risks, managements are expected to focus on the power of the working network.

\section{B. Implication on the Regulators}

Considering the big effect of legal risks on the continuance intention of FinTech payment, regulators need to take a stance based on the findings in this research to create a digital community in Indonesia, specifically among millennials in Jakarta. A coordination should be made between the related authorities both from the financial sector, in this case, the Central Bank of Indonesia, and related authorities in making regulations regarding actions and crimes on FinTech payment manipulation, in this case, the Financial Services Authority, who is the responsible authority in supervising the operation of the financial industry.

\section{Suggestions}

Regardless of the aforementioned contributions, this research has several limitations, therefore, the author delivers suggestions for future research as follows:

1. Future research should explore other factors of benefits and risks to the use of FinTech, which are likely to start showing some significance from time to time [16].

2. This research does not discuss the actual usage behavior in the submitted model. The following research may investigate the causality between the intentionality and the service quality [20].

3. The respondents in this research are limited in their work location, age included (in the millennial category), and ownership of bank accounts and FinTech payment accounts. Therefore, future research might need to broaden this research into other FinTech products, such as peer-to-peer lending or crowdfunding [8].

\section{APPENDIX}

\section{A. Measurement Items}

TABLE V: STRUCTURE OF THE SURVEY INSTRUMENT

\begin{tabular}{lll}
\hline \hline \multicolumn{1}{c}{ Construct } & & \multicolumn{1}{c}{ Statement } \\
\hline $\begin{array}{l}\text { Continuance } \\
\text { Intention of } \\
\text { FinTech }\end{array}$ & CI1: & $\begin{array}{l}\text { Positively considering FinTech payment as an } \\
\text { option } \\
\text { Payment (CI) }\end{array}$ \\
& CI3: & $\begin{array}{l}\text { Preferring FinTech payment service more than other } \\
\text { services }\end{array}$ \\
& CI4: & Using FinTech payment in the future \\
Economic & EB1: & Get cheaper products by using FinTech payment \\
Benefits (EB) & EB2: & Saving more money by using FinTech payment
\end{tabular}


EB3: By using FinTech payment, it is possible to use multiple services with low cost

Seamless

Transactions

(ST)

ST1: Usage of FinTech payment can control money without medium

ST2: Possible to use multiple financial services at the same time while using FinTech payment

ST3: Possible to make payment between merchants and users without medium while using FinTech payment

Convenience CN1: Possible to use financial services very quickly while (CN) using FinTech payment

CN2: Possible to use financial services anywhere and anytime while using FinTech payment

CN3: Possible to use financial services easily while using FinTech payment

Financial Risks (FR)

Legal Risks (LR)

Security

Risks (SR)

1. Any concern on the abuse of financial information while using FinTech payment

SR2: Financial information is unsafe while using FinTech payment

SR3: Any concern on unauthorized access to financial information while using FinTech payment

Operational OR1: FinTech payment companies would not solve Risks (OR) problems when financial loss or financia information leak happens

OR2: FinTech payment companies respond too slowly when financial loss or financial information leak happens

OR3: Any concerns on the way FinTech paymen companies handle financial loss or financial information leak

Perceived PB1: Using FinTech payment has many advantages

Benefits (PB) PB2: Using FinTech payment is easier and faster

PB3: Using FinTech payment is beneficial

PB4: FinTech payment gives better quality than traditional financial services

Perceived PR1: Using FinTech payment is related to high-level risks

Risks (PR) PR2: High uncertainties in using FinTech payment

PR3: FinTech payment gives fewer benefits than traditional financial services

\section{B. Classifications of the User Types}

TABLE VI: FINTECH USER CLASSIFICATION

\begin{tabular}{ll}
\hline \hline User Types & \multicolumn{1}{c}{ Statement } \\
\hline $\begin{array}{l}\text { Early } \\
\text { Adopters }\end{array}$ & $\begin{array}{l}\text { I like to take risks } \\
\text { I am interested in new technology } \\
\text { I tend to be the first in using new products and services }\end{array}$ \\
Late & $\begin{array}{l}\text { I hesitate to take risks } \\
\text { Adopters }\end{array}$ \\
& $\begin{array}{l}\text { I worry about new technology } \\
\text { I prefer to use existing products and services }\end{array}$ \\
\hline \hline
\end{tabular}

\section{REFERENCES}

[1] Kementerian Pemberdayaan Perempuan dan Perlindungan Anak, Statistik gender tematik: profil generasi milenial indonesia. Jakarta: Kementerian Pemberdayaan Perempuan dan Perlindungan Anak, 2018.

[2] DBS, "Rahasia Perkembangan Fintech di Indonesia, Industri Digital yang Sedang Berkembang Pesat," DBS, 2018. [Online]. Available: https://www.dbs.com/spark/index/id_id/site/pillars/2018-rahasiaperkembangan-fintech-di-indonesia-industri-digital-yang-sedangberkembang-pesat.html.

[3] H. S. Ryu, "What makes users willing or hesitant to use Fintech?: the moderating effect of user type," Ind. Manag. Data Syst., vol. 118, no. 3, pp. 541-569, 2018.

[4] L. P. Supratman, "Penggunaan Media Sosial oleh Digital Native," J. ILMU Komun., vol. 15, no. 1, pp. 47-60, 2018.

[5] F. Margaretha, "Dampak Electronic Banking terhadap Kinerja Perbankan Indonesia," J. Keuang. dan Perbank., vol. 19, no. 3, pp. 514-524, 2015.

[6] Lembaga Penjamin Simpanan, "Distribusi Simpanan Bank Umum Periode November 2018," no. November, p. 5, 2018

[7] A. Teja, "Indonesian Fintech Business : New Innovations or Foste and Collaborate in Business Ecosystems? 2 . Literature Study and Hypothesis Development," Asian J. Technol. Manag., vol. 10, no. 1, pp. 10-18, 2017.

[8] I. Trinugroho, H. Sri, R. Sawitri, M. Juan, and S. Toro, "How Ready are People for Cashless Society?," vol. 21, no. 040, pp. 105-112, 2017

[9] N. J. Hanson-rasmussen and K. J. Lauver, "Environmental responsibility : millennial values and cultural dimensions," 2017.

[10] J. Y. A. Leen, R. Thurasamy, and A. Omar, "Engaging Millennials in an evolving web environment: Some key points for e-retailers," Bus. Strateg. Ser., vol. 13, no. 3, pp. 111-117, 2012.

[11] D. K. C. Lee and G. S. Teo, "Emergence of Fintech and the Lasic Principles," SSRN Electron. J., 2015.

[12] S. Okazaki and F. Mendez, "Exploring convenience in mobile commerce: Moderating effects of gender," Comput. Human Behav., vol. 29, no. 3, pp. 1234-1242, 2013

[13] C. Kim, M. Mirusmonov, and I. Lee, "An empirical examination of factors influencing the intention to use mobile payment," Comput. Human Behav., vol. 26, no. 3, pp. 310-322, 2010.

[14] A. Barakat and K. Hussainey, "Bank governance, regulation, supervision, and risk reporting: Evidence from operational risk disclosures in European banks," Int. Rev. Financ. Anal., vol. 30, pp. 254-273, 2013

[15] T. Escobar-Rodríguez and M. Romero-Alonso, "The acceptance of information technology innovations in hospitals: Differences between early and late adopters," Behav. Inf. Technol., vol. 33, no. 11, pp. 1231-1243, 2014

[16] M. Tingchi Liu, J. L. Brock, G. Cheng Shi, R. Chu, and T. H. Tseng, "Perceived benefits, perceived risk, and trust: Influences on consumers' group buying behaviour," Asia Pacific J. Mark. Logist., vol. 25, no. 2, pp. 225-248, 2013.

[17] H. Komulainen, S. Saraniemi, and P. Ulkuniemi, "End-customer value restructuring the financial service supply chain," vol. 36 , no. 6 , pp 709-720, 2018

[18] A. Benlian and T. Hess, "Opportunities and risks of software-as-aservice: Findings from a survey of IT executives," Decis. Support Syst., vol. 52, no. 1, pp. 232-246, 2011

[19] D. Chen, X. Liu, and C. Wang, "Social Trust and Bank Loan Financing: Evidence from China," Abacus, vol. 52, no. 3, pp. 374 403, 2016.

[20] S. Abramova and R. Böhme, "Perceived benefit and risk as multidimensional determinants of bitcoin use: A quantitative exploratory study," 2016 Int. Conf. Inf. Syst. ICIS 2016, no. Zohar 2015, pp. 1-20, 2016.

[21] M. Annette, "The fintech revolution," London Bus. Sch. Rev., vol. 26, no. 3, pp. 50-53, 2015.

[22] E. Lee and B. Lee, "Herding behavior in online P2P lending: An empirical investigation," Electron. Commer. Res. Appl., vol. 11, no. 5, pp. 495-503, 2012.

[23] D. Belanche, L. V. Casaló, and C. Flavián, "Artificial Intelligence in FinTech: understanding robo-advisors adoption among customers," Ind. Manag. Data Syst., 2019

[24] L. Zavolokina, M. Dolata, and G. Schwabe, "FinTech - What's in a Name?," Thirty Seventh Int. Conf. Inf. Syst., pp. 1-16, 2016.

[25] Y. C. Shen, C. Y. Huang, C. H. Chu, and C. T. Hsu, "A benefit-cost perspective of the consumer adoption of the mobile banking system," Behav. Inf. Technol., vol. 29, no. 5, pp. 497-511, 2010.

[26] C. I. Mbama and P. O. Ezepue, "Digital banking, customer experience 
and bank financial performance UK customers ' perceptions," Int. J. Bank Mark., vol. 36, no. 2, pp. 230-255, 2018.

[27] S. Forsythe, C. Liu, D. Shannon, and L. C. Gardner, "Development of a scale to measure the perceived benefits and risks of online shopping," J. Interact. Mark., vol. 20, no. 2, pp. 55-75, 2006.

[28] A. W. Ng and B. K. B. Kwok, "Emergence of Fintech and cybersecurity in a global fi nancial centre Strategic approach by a regulator," vol. 25, no. 4, pp. 422-434, 2017.

[29] W. Brammertz and A. I. Mendelowitz, "From digital currencies to digital fi nance : the case for a smart fi nancial contract standard," 2017.

[30] H. Stewart and J. Jürjens, "Data security and consumer trust in FinTech innovation in Germany," 2018.

[31] E. Y. Yildirim, G. Akalp, S. Aytac, and N. Bayram, "Factors influencing information security management in small- and mediumsized enterprises: A case study from Turkey," Int. J. Inf. Manage., vol. 31, no. 4, pp. 360-365, 2011.

[32] L. H. C. Pinochet, G. T. Diogo, E. L. Lopes, E. Herrero, and R. L. P. Bueno, "Propensity of contracting loans services from FinTech's in Brazil,” Int. J. Bank Mark., vol. 37, no. 5, pp. 1190-1214, 2019.

[33] P. G. Schierz, O. Schilke, and B. W. Wirtz, "Understanding consumer acceptance of mobile payment services: An empirical analysis,' Electron. Commer. Res. Appl., vol. 9, no. 3, pp. 209-216, 2010.

[34] A. Chockalingam, S. Dabadghao, and R. Soetekouw, "Strategic risk , banks , and Basel III : estimating economic capital requirements," vol. 19, no. 3, pp. 225-246, 2018.

[35] A. Aloqab, F. Alobaidi, and B. Raweh, "Operational Risk Management in Financial Institutions: An Overview," Bus. Econ. Res., vol. 8, no. 2, p. 11, 2018.

[36] H. Lee, H. Park, and J. Kim, "Why do people share their context information on social network services? a qualitative study and an experimental study on users' behavior of balancing perceived benefit and risk," Int. J. Hum. Comput. Stud., vol. 71, no. 9, pp. 862-877, 2013.

[37] Y. Liu, Y. Yang, and H. Li, "A Unified Risk-Benefit Analysis Framework for Investigating Mobile Payment Adoption," 2012 Int Conf. Mob. Bus. Proc., p. Paper 20, 2012.

[38] K. Still, T. Huhtala, and S. Saraniemi, "FinTech as business and innovation ecosystems," Proc. ISPIM Conf., no. December, pp. 1-12, 2016

[39] M. Brody et al., "Three financial regulators issue reports on product and service innovations," vol. 18, no. 1, pp. 84-91, 2017.

[40] N. Singh, S. Srivastava, and N. Sinha, "Consumer preference and satisfaction of M-wallets: a study on North Indian consumers," Int. J. Bank Mark., vol. 35, no. 6, pp. 944-965, 2017.

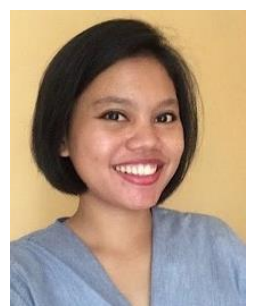

Norma Diana was born in Jakarta. She earned her bachelor's degree in philosophy studies from the University of Indonesia, and the master's degree in finance and risk management from Trisakti University. She has been working for several FinTech companies, both national and multinational - in several kind of FinTech industries. Currently, she is working with the leading online $\mathrm{P} 2 \mathrm{P}$ lending company in Indonesia and conduct several projects. Her research interests are in the financial inclusion, technology, and strategic management areas.

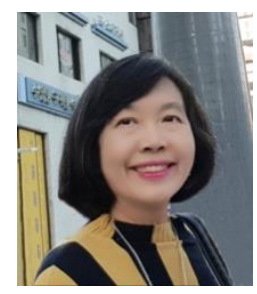

Farah Margaretha Leon was born in Jakarta She has a bachelor's degree in business administration at the Faculty of Economics, Trisakti University; the master of economics at Faculty of Economics and Business, University of Indonesia; and the Ph.D in finance from the University of Malaya. Currently, she is a professor and lecturer of the Faculty of Economics and Business, Trisakti University, Jakarta Indonesia. Her research interest is in the area of financial management, corporate finance, personal finance, capital market, and investment. 